Original Article

แ.

\title{
Synthesis and Rice-Blast Control Activity of Sulfonylamidines*
}

\author{
Tsuneo Iwakawa, Hiroto Tamura, Michio Masuko, \\ Akira Murabayashi and Yoshio Hayase \\ Aburahi Laboratories, Shionogi \& Co., Ltd., Koka-cho, Koka-gun, Shiga 520-34, Japan
}

(Received November 19, 1991 ; Accepted February 28, 1992)

\begin{abstract}
A series of sulfonylamidines with a cleaved type of thiadiazine ring between the N-4 and C-benzene bond in 1,2,4-benzothiadiazine 1,1-dioxide were prepared, and their rice-blast control activity was examined. Some of these compounds exhibited good activity by foliar application. Substituents appeared to be important for the activity. The most effective was $N$-(C-Diethylamino- $n$-hexylmethylene)- $p$-toluenesulfonamide (24), the activity of which was stronger than that of $O, O$-diisopropyl $S$-benzyl phosphorothiolate (IBP).
\end{abstract}

\section{INTRODUCTION}

3-Alkylthio-1,2,4-benzothiadiazine 1,1-dioxides ( $\mathbf{A}$ in Fig. 1) are reported to have shown some control activity against rice-blast. ${ }^{1)}$ This study was aimed to obtain a new type of fungicide that is structurally related to $\mathbf{A}$ but more effective.

Judging from the structure-activity requirements of $\mathbf{A}$, we speculated that the activity might be primarily attributable to the sulfonylamidine moiety, but substituents also must have a role in providing adequate activity. Based on the structure-activity requirements of $\mathbf{A}$, we designed open-chain sulfonylamidine analogs (B in Fig. 1) derived from $\mathbf{A}$ in which the nitrogen-to-carbon bond between $\mathrm{N}-4$ and C-benzene of $\mathbf{A}$ was cleaved.

This paper reports the synthesis of various kinds of sulfonylamidine derivatives and their structure-activity relationships.

\section{MATERIALS AND METHODS}

\section{Chemicals}

Sulfonylamidines were prepared by the $[2+2]$ cycloaddition reaction of sulfonyliso-

* Cycloaddition in Synthesis of Sulfonamide Derivatives (Part 5). For Part 4, see Ref. 5). cyanate with carbonyl or thiocarbonyl compounds with the synthetic scheme shown in Fig. 2. The synthestic method has been described in detail in the patent ${ }^{2)}$ and papers $^{3-5)}$ on this series of compounds. 3Ethylthio-4-methyl-4H-1,2,4-benzothiadiazine 1,1-dioxide was prepared according to our reported method.6) The configuration of the sulfonylamidines reported here remains undetermined. Structures of the compounds were confirmed by ${ }^{1} \mathrm{H}$ NMR, IR spectra and/or elemental analysis $(\mathrm{C}, \mathrm{H}, \mathrm{N})$. All melting points are uncorrected.

\section{Disease-controlling Activity}

Disease-controlling activity was assessed after preventive foliar application. Two-weekold rice seedlings (var.: AICHI-ASAHI) were transplanted into plastic cups and cultivated for 2 weeks. The test compound in a form of solution or suspension was sprayed on the foliage of the rice seedlings. The test solution or suspension was prepared by dissolving the compound in a small amount of $N, N$-dimethylformamide followed by dilution with distilled water containing a sticking agent to the desired concentration. The test plants were inoculated by spraying with a conidial suspension of Pyricularia oryzae previously cul- 
tured on an oatmeal medium.

After being sprayed with the conidial suspension, the test plants were kept in a moist chamber $\left(28^{\circ} \mathrm{C}, 100 \%\right.$ R.H. $)$ for 24 hours, followed by incubation in a greenhouse for 5 days. Six day after inoculation, the number of lesions was counted and the percent of control was calculated as follows:

$$
\text { Control }(\%)=(1-b / a) \times 100 \text {, }
$$

where $a$ is the number of lesions in an un-

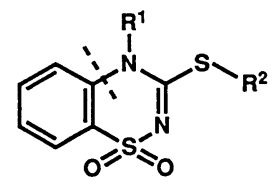

A

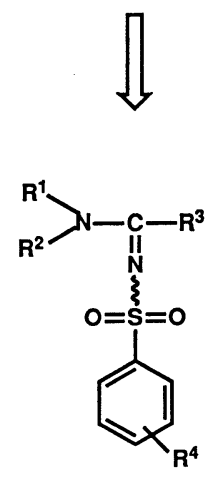

B

Fig. 1 The original lead and prepared compounds. treated plot and $b$ is the number of lesions in a treated plot.

\section{RESULTS AND DISCUSSION}

1. Effect of Carbon Substituents ( $R^{3}$ in Fig. 2) and Amino Moiety $\left(R^{1}, R^{2}\right.$ in Fig. 2)

The physical properties and rice-blast control activities of the tested compounds are listed in Tables 1 to 5 .

At first, the effect of $\mathrm{R}^{3}$ on the rice-blast control activity was examined with various kinds of prepared compounds in which $\mathrm{R}^{1}, \mathrm{R}^{2}$ were fixed as methyl and $\mathrm{R}^{4}$ as 4-methyl (Tables 1 and 2). In a series of phenyl deriva-

Table 1 Rice-blast control activity of $N-(C$ dimethylamino - phenylmethylene) - $p$ - toluenesulfonamides.

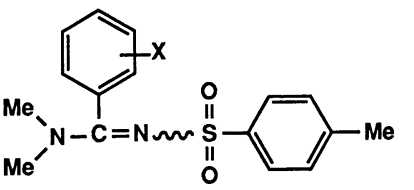

\begin{tabular}{clcc}
\hline $\begin{array}{c}\text { Compound } \\
\text { No. }\end{array}$ & $\mathrm{X}$ & $\mathrm{mp}\left({ }^{\circ} \mathrm{C}\right)$ & $\begin{array}{c}\text { Control } \\
(\%) \\
(500 \mathrm{ppm})\end{array}$ \\
\hline $\mathbf{1}$ & $\mathrm{H}$ & $160-161$ & 30 \\
$\mathbf{2}$ & $4-\mathrm{CH}_{3}$ & $118-119$ & 70 \\
$\mathbf{3}$ & $4-\mathrm{OCH}_{3}$ & $132-133$ & 70 \\
$\mathbf{4}$ & $4-\mathrm{N}\left(\mathrm{CH}_{3}\right)_{2}$ & $155-157$ & 0 \\
$\mathbf{5}$ & $4-\mathrm{Cl}_{6}$ & $185-188$ & 0 \\
$\mathbf{6}$ & $4-\mathrm{NO}_{2}$ & $188-190$ & 0 \\
$\mathbf{7}$ & $3,4-\mathrm{Cl}_{2}$ & $160-161$ & 50 \\
$\mathbf{8}$ & $2-\mathrm{CO}_{2} \mathrm{CH}_{3}$ & $134-135$ & 0 \\
\hline
\end{tabular}

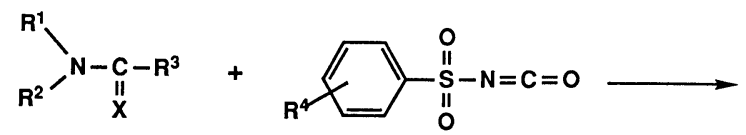

$X=0, s$

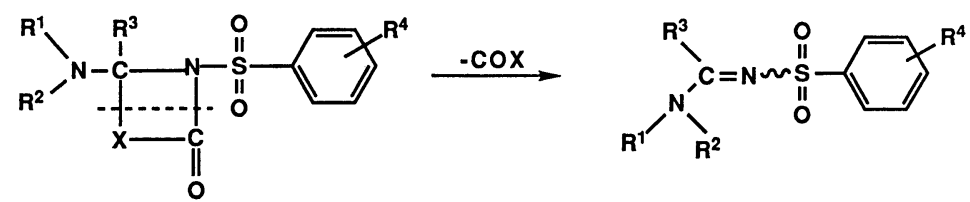

Fig. 2 General synthetic route. 
Table 2 Rice-blast control activity of $N$ (C-dimethylamino-methylene) - $p$ - toluenesulfonamides.

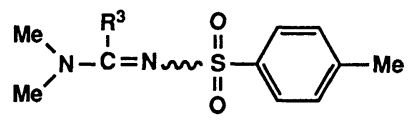

\begin{tabular}{rllc}
\hline $\begin{array}{c}\text { Compound } \\
\text { No. }\end{array}$ & \multicolumn{1}{c}{$\mathrm{R}^{3}$} & $\mathrm{mp}\left({ }^{\circ} \mathrm{C}\right)$ & $\begin{array}{c}\text { Control } \\
(\%) \\
(500 \mathrm{ppm})\end{array}$ \\
\hline $\mathbf{9}$ & $\mathrm{CH}_{3}$ & $120-123$ & 70 \\
$\mathbf{1 0}$ & $n-\mathrm{C}_{3} \mathrm{H}_{7}$ & oil & 70 \\
$\mathbf{1 1}$ & $\mathrm{CH}=\mathrm{CH}-\mathrm{CH}_{3}$ & $147-149$ & 30 \\
$\mathbf{1 2}$ & $\mathrm{CH}_{2} \mathrm{CH}(\mathrm{Br}) \mathrm{CH}_{3}$ & $103-104.5$ & 30 \\
$\mathbf{1 3}$ & $n-\mathrm{C}_{6} \mathrm{H} \mathrm{H}_{13}$ & oil & 70 \\
$\mathbf{1 4}$ & $\mathrm{C}_{6} \mathrm{H}_{11}(\mathrm{cyc})$ & $121-121.5$ & 50 \\
$\mathbf{1 5}$ & $\mathrm{OCH}_{3}$ & $92-94$ & 0 \\
$\mathbf{1 6}$ & $\mathrm{SCH}_{3}$ & $59-60$ & 30 \\
$\mathbf{1 7}$ & $\mathrm{N}\left(\mathrm{CH}_{3}\right)_{2}$ & $140-141$ & 30 \\
$\mathbf{1 8}$ & $\mathrm{COOEt}$ & $121-123$ & 50 \\
\hline
\end{tabular}

Table 3 Rice-blast control activity of $N$ (C-diethylamino - methylene) - $p$ - toluenesulfonamides.

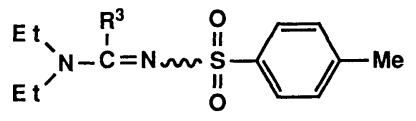

\begin{tabular}{cllc}
\hline $\begin{array}{c}\text { Compound } \\
\text { No. }\end{array}$ & \multicolumn{1}{c}{$\mathrm{R}^{3}$} & $\mathrm{mp}\left({ }^{\circ} \mathrm{C}\right)$ & $\begin{array}{c}\text { Control } \\
(\%) \\
(500 \mathrm{ppm})\end{array}$ \\
\hline $\mathbf{1 9}$ & $i-\mathrm{Pr}$ & $87-88$ & 0 \\
$\mathbf{2 0}$ & $i-\mathrm{Bu}$ & oil & 0 \\
$\mathbf{2 1}$ & $t-\mathrm{Bu}$ & $77-80$ & 0 \\
$\mathbf{2 2}$ & $n-\mathrm{Bu}$ & oil & 70 \\
$\mathbf{2 3}$ & $n-\mathrm{C}_{5} \mathrm{H}_{11}$ & oil & 90 \\
$\mathbf{2 4}$ & $n-\mathrm{C}_{6} \mathrm{H}_{13}$ & oil & 97 \\
$\mathbf{2 5}$ & $\mathrm{C}_{6} \mathrm{H}_{11}(\mathrm{cyc})$ & $102-105$ & 30 \\
$\mathbf{2 6}$ & $n-\mathrm{C}_{7} \mathrm{H}_{15}$ & oil & 90 \\
$\mathbf{2 7}$ & $n-\mathrm{C}_{8} \mathrm{H}_{17}$ & oil & 70 \\
$\mathbf{2 8}$ & $n-\mathrm{C}_{9} \mathrm{H}_{19}$ & oil & 50 \\
$\mathbf{2 9}$ & $n-\mathrm{C}_{10} \mathrm{H}_{21}$ & oil & 50 \\
$\mathbf{3 0}$ & $n-\mathrm{C}_{11} \mathrm{H}_{23}$ & oil & 50 \\
$\mathbf{3 1}$ & $n-\mathrm{C}_{13} \mathrm{H}_{27}$ & $48-49$ & 30 \\
$\mathbf{3 2}$ & $n-\mathrm{C}_{15} \mathrm{H}_{31}$ & $59-59.5$ & 0 \\
\hline
\end{tabular}

tives, the activity was greatly influenced by a substituent of the benzene ring. Compounds $\mathbf{2}$ and $\mathbf{3}$ which had methyl and methoxy at the 4-position of the benzene ring, respectively, were highly active, whereas 4-dimethylamino
Table 4 Rice-blast control activity of $N-(C$ amino- $n$-hexylmethylene)- $p$-toluenesulfonamides.

$\substack{\text { Compound } \\ \text { No. }}$
33
36

(4), 4-chloro (5), 4-nitro (6) and 2-methoxycarbonyl (8) derivatives were inactive. Compounds $\mathbf{1}$ and $\mathbf{7}$ had lower activity (Table 1).

To define more detailed requirements of substituents $\left(\mathrm{R}^{3}\right)$, various substituents were introduced and the activity was tested. As can be seen from Table 2, a series of alkyl analogs $(\mathbf{9}, \mathbf{1 0}, \mathbf{1 3})$ showed high activity, whereas a cyclohexyl-substituted compound (14) and a methylthio-substituted compound (16) lowered the activity and a methoxy-substituted compound (15) gave an ineffective compound. Introduction of a bromine atom or a double bond into the $n$-propyl group $(\mathbf{1 1}, \mathbf{1 2})$ decreased the activity. Dimethylamino-(17) and carboethoxy-substituted compound (18) also lowered the activity. These data revealed alkyl groups are favorable for high activity.

When $\mathrm{R}^{3}$ was $n$-hexyl, compounds with ethyl as substituents in $\mathrm{R}^{1}$ and $\mathrm{R}^{2}(\mathbf{2 4})$ showed higher activity than those with methyl (13), $n$-propyl (33) and $n$-butyl (34). The effect of amino moiety on the activity was then examined. Introduction of a cyclic amino group (35-38) resulted in reduced activity (Table 4), 
which indicated the importance of diethylamino substituents. The activity of a piperidine analog (35) was higher than that of pyrrolidine, 1-methylpiperadine and morpholine analogs (36-38). Based on these findings various kinds of alkyl substituted derivatives having ethyl at $\mathrm{R}^{1}$ and $\mathrm{R}^{2}$ were prepared and examined (Table 3).

Compounds with a branched alkyl group (19-21) showed no activity and a cyclohexylsubstituted compound (25) had only low activity. Compounds with an unbranched alkyl group $(\mathbf{2 3}, \mathbf{2 4}, \mathbf{2 6})$, in contrast, had high activity. The effect of unbranched alkyl substituents on the activity depended on the length of the carbon chain, with the potency decreasing in the following order: 23, 24, 26 $(\mathrm{C} 5-\mathrm{C} 7)>\mathbf{2 2}, \mathbf{2 7}(\mathrm{C} 4)(\mathrm{C} 8)>\mathbf{2 8}-\mathbf{3 0}(\mathrm{C} 9-\mathrm{C} 11)>$ $31(\mathrm{C} 13)>32(\mathrm{C} 15)$.

\section{Effect of Benzene Ring Substituents ( $R^{4}$ in} Fig. 2)

Since compound $\mathbf{2 4}$ showed high activity, we next examined the effect of ring substituents by a benzene sulfonyl group. As shown in Table 5, introduction of a chlorine atom at the 4-position of the benzene ring (39) decreased the activity. A 2-chloro derivative (40) had no activity, and an unsubstituted compound (41) had low activity. These results indicate that the activity is greatly dependent on the type of substituents as well as the position of substitution on the benzene ring.

\section{Activity of Selected Compounds}

Based on the above results, compounds $\mathbf{2 3}$,

Table 5 Rice-blast control activity of $N-(C$ diethylamino - $n$-hexylmethylene) - $p$ - toluenesulfonamides.

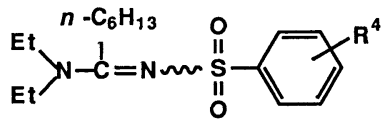

\begin{tabular}{clcc}
\hline $\begin{array}{c}\text { Compound } \\
\text { No. }\end{array}$ & $\mathrm{R}^{\mathbf{4}}$ & $\mathrm{mp}\left({ }^{\circ} \mathrm{C}\right)$ & $\begin{array}{c}\text { Control } \\
(\%) \\
(500 \mathrm{ppm})\end{array}$ \\
\hline $\mathbf{3 9}$ & $4-\mathrm{Cl}$ & oil & 30 \\
$\mathbf{4 0}$ & $2-\mathrm{Cl}$ & oil & 0 \\
$\mathbf{4 1}$ & $\mathrm{H}$ & oil & 30 \\
\hline
\end{tabular}

Table 6 Selected compounds and their controlling activities on rice blast by foliar application.

\begin{tabular}{|c|c|c|c|c|}
\hline \multirow[b]{2}{*}{ Compound } & \multicolumn{4}{|c|}{ Control (\%) } \\
\hline & $\begin{array}{c}500 \\
\text { ppm }\end{array}$ & $\begin{array}{r}125 \\
\text { ppm }\end{array}$ & $\begin{array}{l}31.3 \\
\mathrm{ppm}\end{array}$ & $\begin{array}{r}7.8 \\
\text { ppm }\end{array}$ \\
\hline 23 & 90 & 90 & 70 & 30 \\
\hline 24 & 97 & 90 & 90 & 50 \\
\hline 26 & 90 & 90 & 70 & 30 \\
\hline IBP $\left.^{a}\right)$ & 70 & 50 & 30 & 0 \\
\hline $\begin{array}{l}\text { 3-Ethylthio-4-methyl- } \\
\text { 1,2,4-benzothiadiazine } \\
\text { 1,1-dioxide }\end{array}$ & 90 & 70 & 30 & 0 \\
\hline
\end{tabular}

a) $O, O$-diisopropyl $S$-benzyl phosphorothiolate.

24, 26 were chosen for the second step of evaluation. Compound $\mathbf{2 4}$ showed sufficient control even at $31.3 \mathrm{ppm}$, being more active than $O, O$-diisopropyl $S$-benzyl phosphorothiolate (IBP) and the original lead compound, 3-ethylthio-4-methyl-1,2, 4-benzothiadiazine 1,1-dioxide $\left(\mathbf{A}, \mathrm{R}^{1}=\mathrm{Me}, \mathrm{R}^{2}=\mathrm{Et}\right)$ (Table 6).

Our study has revealed that these sulfonylamidine derivatives are a new class of fungicides that are highly effective against riceblast.

\section{ACKNOWLEDGMENTS}

We wish to express our thanks to Dr. Yoshiyuki Hayashi, Director of the Aburahi Laboratories of Shionogi \& Co., Ltd., for his encouragement and permission to publish this work.

\section{REFERENCES}

1) H. Ohyama, S. Hobara \& T. Wada (Hokko Chemical Industry Co., Ltd.): Jpn. Kokai Tokkyo Koho JP 60-97970 (1985)

2) Y. Hayase, T. Iwakawa, M. Masuko \& H. Tamura (Shionogi \& Co., Ltd.): Jpn. Kokai Tokkyo Koho JP 1-272565 (1989)

3) T. Iwakawa, H. Tamura, T. Sato \& Y. Hayase: Chem. Pharm. Bull. 36, 4755 (1988)

4) H. Tamura, T. Iwakawa \& Y. Hayase: Chem. Pharm. Bull. 38, 1069 (1990)

5) T. Iwakawa, H. Tamura, A. Murabayashi \& Y. Hayase: Chem. Pharm. Bull. 39, 1939 (1991)

6) T. Iwakawa, H. Tamura \& Y. Hayase: Chem. Pharm. Bull. 38, 1075 (1990) 


\section{要 約}

スルホニルアミジン誘導体の合成といもち病防 除活性*

岩川恒男, 田村廣人, 益子道生 村林 旭, 早瀬善男 3-アルキルチオー1,2,4-ベンゾチアジアジン 1,1-ジオ キシドがいもち病防除活性を有することに着目し，この

* 環状付加反応を利用したスルホンアミド誘導体の合 成研究（第 5 報）
化合物のスルホニルアミジン部が活生発現に求められる 必須構造ではないかと推論した．この推論に基づいて種 種の 置換基を有するスルホニルアミジン誘導体を合成 し，その構造と生物活性の関係を検討した．その結果， 合成した化合物群のいくつかが，優れた活性を示した.

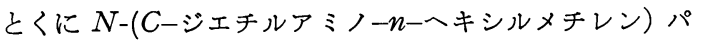
ラトルエンスルホンアミドは，リード化合物および $O$, Oージイソプロピル S-ベンジルフォスフォロチオレート (IBP) よりも，いもち病に対して高い防除活性を示し た. 